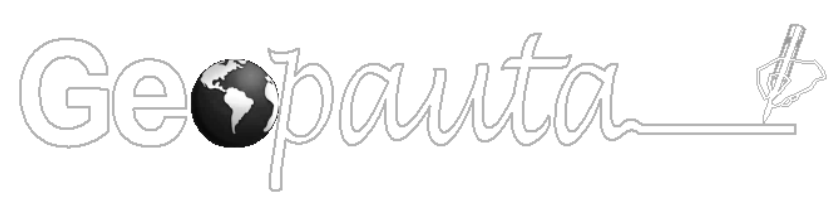

Volume 4, n‥ 2, 2020

ISSN: 2594-5033

http://periodicos2.uesb.br/index.php/geo

DOI: https://doi.org/10.22481/rg.v4i2.6154

\title{
Dinâmica e evolução do emprego e desenvolvimento humano em Porto Nacional-TO: perspectivas e realidades
}

\section{Dynamics and evolution of employment and human development in Porto National-TO: prospects and realities}

\section{Dinámica y evolución del empleo y el desarrollo humano en Porto National-TO: perspectivas y realidades}

Jaciara Araújo de Moura ${ }^{1}$ http://orcid.org/0000-0002-0394-7932

Roberto de Souza Santos ${ }^{2}$ http://orcid.org/0000-0002-4373-6443

\footnotetext{
${ }^{1}$ Graduada e licenciada em Geografia pela Universidade Federal de Tocantins, UFT-TO- Porto Nacional - Tocantins- Brasil, Professora na rede publica municipal de ensino em Porto Nacional-TO - email - jaciaraujo007@ hotmail.com

${ }^{2}$ Professor doutor no curso de Geografia e professor efetivo do curso de Pos-graduaçao em Geografia Campus Universitario de Porto Nacional - Tocantins - Brasil, email - robertosantos@uft.edu.br
}

\section{Resumo}

O presente artigo é resultado de pesquisa de iniciação científica. A análise teórica baseou-se em uma revisão bibliográfica e a análise empírica baseou-se em um trabalho de campo com a aplicação de entrevistas e na coleta de dados estatísticos sobre emprego no banco de dados do Instituto Brasileiro de Geografia e estatística e no Atlas de Desenvolvimento Humano de 2000 e 2013. Tem como objetivo analisar, avaliar a dinâmica do emprego, a evolução e o desenvolvimento humano em Porto Nacional-TO. A investigação empírica foi desenvolvida a partir de dados estatísticos coletados no banco de dados do IBGE e PNUD e de entrevistas com líderes sindicais. Os resultados desta pesquisa estão expostos na forma de tabelas e de gráficos no texto.

Palavras-chave: Emprego. Trabalho. Desenvolvimento humano.

\begin{abstract}
This article is the result of research of scientific initiation. The theoretical analysis was based on a bibliographic review and the empirical analysis was based on field work with the application of interviews and the collection of statistical data on employment in the database of the Brazilian Institute of Geography and Statistics and the Atlas de Human Development 2000 and 2013. Its objective is to analyze, evaluate employment dynamics, evolution and human development in Porto Nacional-TO. The empirical investigation was developed from statistical data collected in the IBGE and UNDP database and interviews with union leaders. The results of this research are shown in the form of tables and graphs in the text.
\end{abstract}

Keywords: Employment. Work. Human development.

\section{Resumen}

Este artículo es el resultado de una investigación de iniciación científica. El análisis teórico se basó en una revisión bibliográfica y el análisis empírico se basó en el trabajo de campo con la aplicación de entrevistas y 
la recopilación de datos estadísticos sobre el empleo en la base de datos del Instituto Brasileño de Geografía y Estadística y el Atlas de Desarrollo Humano 2000 y 2013. Su objetivo es analizar, evaluar la dinámica del empleo, la evolución y el desarrollo humano en Porto Nacional-TO. La investigación empírica se desarrolló a partir de datos estadísticos recopilados en la base de datos del IBGE y el PNUD y entrevistas con líderes sindicales. Los resultados de esta investigación se muestran en forma de tablas y gráficos en el texto.

Palabras clave: Empleo. Trabajo. Desarrollo humano.

Recebido em: 17/01/2020

Aceito para publicação em: 30/04/2020

Publicado em: 29/06/2020

\section{Introdução}

O município de Porto Nacional é um dos mais antigos do Tocantins. Sua origem histórica vem desde o século XVIII. Segundo Oliveira (2009), o povoado de Porto Nacional teve sua origem por volta da última década do século XVIII e início do século XIX, com a formação de um pequeno povoado conhecido por Arraial Novo do Porto Real do Pontal. Por volta de 1810, já teria se constituído em um centro regional na região. O arraial de Porto Real era circundado por outros arraiais auríferos importantes despertando ao Poder Real, grande interesse pela riqueza mineral (ouro) da região. Apesar de Porto Real (Porto Nacional) não ter ouro, era local de embarque e desembarque de garimpeiros, para localidades estratégicas às margens do rio Tocantins. $O$ transporte da produção mineral era realizado pelo rio Tocantins até Belém-PA. Atualmente, o município de Porto Nacional fica na Mesorregião Oriental e na Microrregião de Porto Nacional do Tocantins, a $52 \mathrm{~km}$ da capital Palmas e, compreende uma área de aproximadamente 4.449,918 $\mathrm{km}^{2}$ distribuída em uma população aproximada de 52.828 habitantes (IBGE, 2017). O mapa 01, abaixo, demonstra a localização geográfica de Porto Nacional.

Em sua história, Porto Nacional teve vários nomes no seu cotidiano, isto é, na época da colonização (sendo chamada de Porto Real), no império (Porto Imperial) e na república (Porto Nacional). A cidade de Porto Nacional em sua história centenária, tem sua identidade ligada no rio Tocantins, onde por muito tempo foi o principal caminho para a chegada de mercadorias e pessoas. A navegação pelo rio Tocantins possibilitou a cidade a se transformar em um centro de referência econômica para a região centro-sul do Tocantins. Mas, a partir da construção da BR-153, que percorre o estado do Tocantins de Norte a Sul, o rio acabou 
perdendo a sua importância. O transporte rodoviário passou sobrepor o hidroviário, e a cidade de Porto Nacional também acabou perdendo à sua importância econômica e geográfica no contexto regional.

Mapa 1 - Localização do municipio de Porto Nacional- Tocantins-Brasil

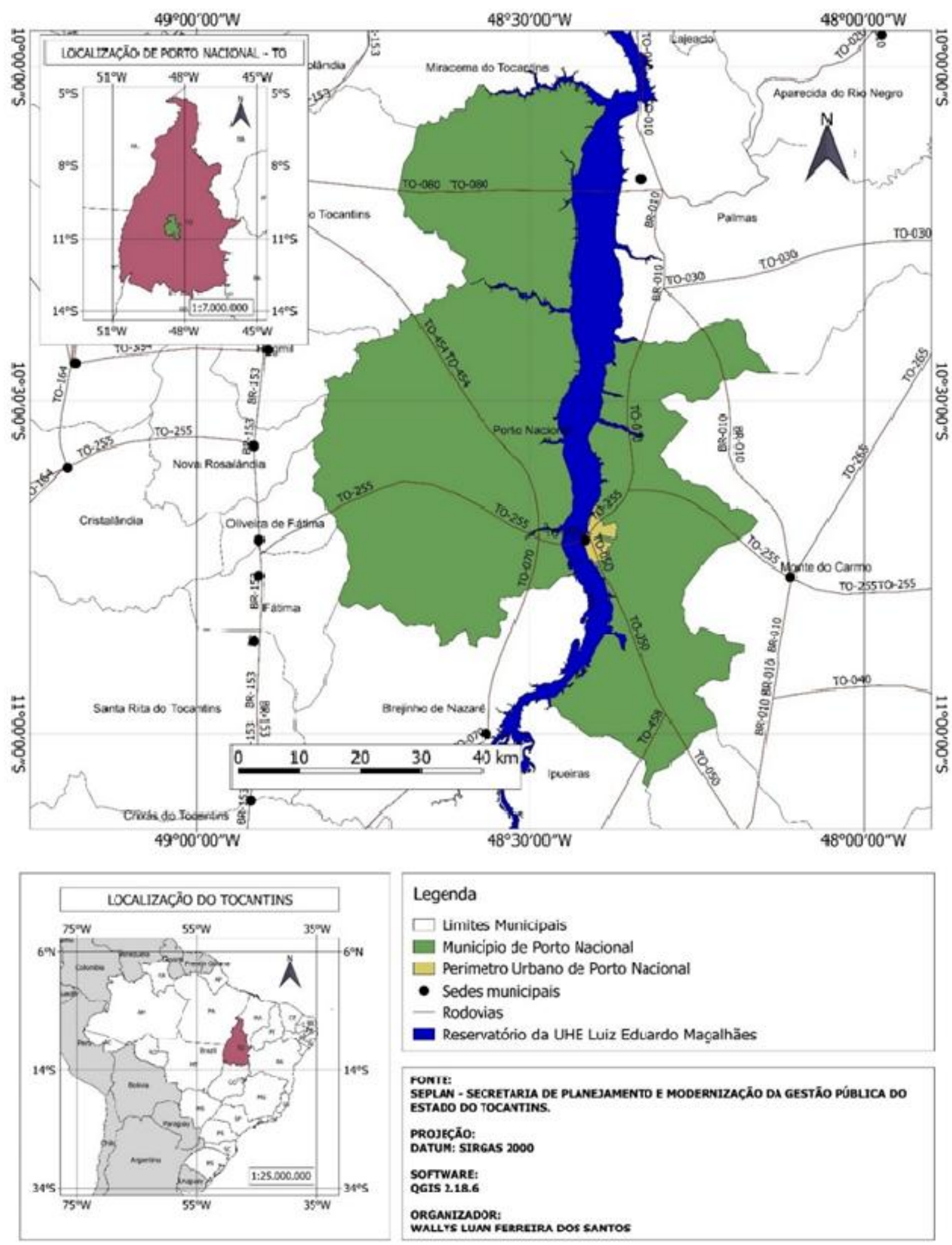

Fonte: Secretaria de Planejamento e Gestão Pública de Tocantins.

Geopauta, Vitória da Conquista, ISSN: 2594-5033, V. 4, n. 2, 2020, (p. 5-29) http://periodicos2.uesb.br/index.php/geo,

Este é um artigo de acesso aberto sob a licença Creative Commons da CC BY 
Atualmente, o transporte ferroviário traçado pela Ferrovia Norte-Sul que passa pelo município, tem grande influência econômica para a região. Principalmente, com a criação do pátio multimodal, localizado na rodovia TO-080, próximo ao povoado de Luzimangue a 12 km de Palmas, com uma área total aproximada de 70 hectares, onde é acomodado tipos de carga de commodities agrícolas, fertilizantes, granéis líquidos/combustíveis. Espera-se que a economia de Porto Nacional tenha novo impulso com a instalação do pátio de integração Multimodal da Ferrovia Norte-Sul (inaugurado em 2010) que interliga as modalidades de transportes rodoviário, ferroviário e fluvial. Com isso, acelera também o processo de desenvolvimento econômico e regional em torno do município.

Por outro lado, é importante observar que a modernização da agricultura, mais precisamente, a partir de 1980, permitiu uma pujança maior da economia do município. Outro fato importante para o município foi a construção de Palmas em 1989, com apenas 63 quilômetros de distância da cidade de Porto Nacional, passou evidenciar um novo panorama na economia do município. Ou seja, a proximidade da cidade de Porto Nacional com a capital Palmas, permitiu que o eixo de desenvolvimento regional relativamente deslocasse do eixo da BR-153 para o Leste na porção centro-sul do estado, beneficiando a microrregião de Porto Nacional. De forma direta ou indireta estes fatos estimularam o desenvolvimento econômico para o município. Entretanto, são fatos pontuais que contribuíram para o desenvolvimento de forma limitada, atingindo o desenvolvimento regional e humano para o município.

A economia de Tocantins se destaca por três setores, isto é, segundo IBGE (2010), o setor de serviços corresponde a 58,1\% do PIB, em seguida vem setor da indústria com $24,1 \%$ e por último o setor da agropecuária que corresponde 17,8\% do PIB estadual. Percebe-se que o estado e em consequência, o município de Porto Nacional, ainda tem uma economia pouco diversificada, o que representa uma economia não consolidada. Mas se compararmos o ranking do município no contexto estadual e, principalmente no contexto da microrregião de Porto Nacional, podemos constatar que a situação do município perante a estas esferas, é confortável. Isto é, de acordo com dados do $\mathrm{IBGE}^{3}$, no ranking entre os 5.570 municípios no país. Porto Nacional, está na posição de $1166^{\circ}$, e no ranking estadual entre os 139 municípios, Porto Nacional está na posição de $11^{\circ}$. Na microrregião de Porto Nacional entre os 11 municípios, Porto Nacional está na posição de $3^{\circ}$ lugar.

A economia do município não diversificada e ainda em desenvolvimento não cria muita expectativa para a criação e a evolução do emprego e para o desenvolvimento humano. Esta tese precisa ser empiricamente verificada através dos dados empíricos e teóricos

\footnotetext{
${ }^{3}$ https://cidades.ibge.gov.br/brasil/to/porto-nacional/panorama

Geopauta, Vitória da Conquista, ISSN: 2594-5033, V. 4, n. 2, 2020, (p. 5-29) http://periodicos2.uesb.br/index.php/geo, 
levantados. O texto a seguir procura discorrer teórica e empiricamente, no intuito de ter um entendimento sobre a evolução e dinâmica do emprego e do desenvolvimento humano em Porto Nacional. O texto procura levantar questões teóricas que possibilitem uma compreensão acerca do tema - dinâmica e evolução do emprego e desenvolvimento humano em Porto Nacional - TO: perspectivas e realidades. A investigação explora as abordagens geográficas que enfocam as relações entre emprego e desenvolvimento humano e evidencia os elementos que constituem a dinâmica e a evolução do emprego em Porto Nacional.

A pesquisa sobre esta temática se justifica pela necessidade de se conhecer o território do emprego, a dinâmica e sua evolução do município de Porto Nacional. Nesse contexto, é necessário que se faça uma discussão sobre o conceito de emprego e trabalho, pautado em autores que possam dar sustentação teórica ao tema debatido. A investigação empírica foi desenvolvida a partir de dados estatísticos coletados no banco de dados do IBGE e PNUD e de entrevistas com líderes sindicais. Os resultados desta pesquisa estão expostos na forma de tabelas, gráficos no texto. Os procedimentos metodológicos da pesquisa apóiam-se, sobretudo, em fontes primárias e secundárias com o objetivo de fornecer subsídios teóricos e empíricos para a análise sobre o tema em pauta.

\section{Pressupostos teórico-metodológicos da pesquisa}

Foi realizada uma revisão bibliográfica sobre a temática da pesquisa - dinâmica e evolução do emprego e desenvolvimento humano em Porto Nacional - TO. A busca de documentos comprobatórios possibilitou a conceituação teórica de emprego e a análise crítica da dinâmica, evolução e desenvolvimento do emprego em Porto Nacional - TO. Por meio de análise dos dados estatísticos levantados nos bancos de dados do IBGE e PNUD, possibilitou o bom andamento da pesquisa e direcionamento das sucessivas etapas de trabalho de campo e da investigação empírica. Este procedimento metodológico permitiu aos autores observar à dinâmica e a evolução do emprego em Porto Nacional - TO.

No trabalho de campo, foram realizadas visitas às associações sindicais dos trabalhadores do setor comercial em Porto Nacional para realização de entrevistas com os líderes sindicais. A partir da revisão bibliográfica e do trabalho de campo foi possível proceder a verificabilidade dos fatos observados. Com este procedimento metodológico possibilitou a elaboração de tabelas e gráficos no Excel com o objetivo de visualizar a dinâmica, a evolução e o desenvolvimento do emprego em Porto Nacional. A análise da dinâmica e evolução do emprego e o desenvolvimento humano em Porto Nacional-TO tem 
como objetivo oferecer subsídios para a compreensão e discussão teórica ampla e aprofundada entre 1995 a 2014.

O conceito chave central em nossa análise é o de noção de emprego e sua espacialidade. Há uma confusão entre emprego e trabalho. Estes conceitos, no entanto, são bastante distintos. Para proporcionar maior clareza, o texto aborda primeiro, sobre a noção de trabalho, e, em seguida, aborda-se o de emprego. Segundo Santos (1999), o período denominado de feudalismo inaugurou novas formas de o homem relacionar-se com o trabalho; pautadas nas necessidades de cada célula feudal: desaparecimento de praticamente todas as profissões (exercidas por homens livres) e artesãos, manutenção dos ofícios (que eram passados de pai para filho, por exemplo: ferreiro, padeiro, etc.) e de status quo - o antigo escravo torna-se servo.

Com a Revolução Francesa inauguram-se novos ideários (liberdade, fraternidade e igualdade), que longe de modificar o sistema de dominação autocrática real, que desde o surgimento das primeiras civilizações tomaram-se a máxima humana, substitui-o por uma nova classe (de antigos homens livres), denominada de burguesia, tão ou mais opressora que a sucedida. Esta nova classe amparada pela ciência, passou a determinar uma relação social diferenciada, não mais somente com base na criação de técnicas para a sobrevivência ou mesmo da propriedade de terras e pessoas, mas também na gestão e formação de capital lucro. É a revolução das ideias, das posturas, das crenças, dos valores, mesclada com o surgimento das indústrias, da ideia de emprego. As pessoas não são mais definidas pelo que elas são, mas pelo que elas fazem, afirma o referido autor. Foi necessário compreender e dominar novas habilidades, além de assimilar horários fixos e adaptar-se a rigidez da tarefa, ou seja, com a industrialização o trabalhador foi transformado em operário.

Segundo Marx (1983, p.149), “[...] o trabalho revela o modo como o homem lida com a natureza, o processo de produção pelo qual ele sustenta a sua vida e, assim, põe a nu o modo de formação de suas relações sociais e das ideias que fluem destas". O trabalho é uma atividade social, necessária ao progresso material e moral da humanidade. O trabalho é tão antigo quanto à humanidade. Pode-se imaginar que, a partir do momento em que o homem tenha tomado consciência de sua individualidade, tenha também tomado consciência do trabalho como atividade indispensável para sua sobrevivência e seu progresso. O trabalho é uma atividade inerente à condição humana e sempre existiu, independentemente, do modo de produção vigente.

Para Albornoz (1988), o trabalho é a atividade correspondente ao artificialismo da existência humana, uma ação correspondente a condição humana. É por meio do trabalho que 
o homem cria coisas a partir do que extrai da natureza, convertendo o mundo num espaço de objetos partilhados. O primeiro é um processo de transformação da natureza para a satisfação das necessidades vitais do homem. O segundo, é um processo de transformação da natureza para responder as necessidades do ser humano. O trabalho é uma atividade do indivíduo que pode se confundir com ocupação. O uso do termo ocupação, em Ciências Sociais, segue o sentido comum, que é o de emprego, negócio ou profissão. A ocupação de uma pessoa é a espécie de trabalho feito por ela, independente da indústria em que esse trabalho é realizado e do status que o emprego confere ao indivíduo. Segundo Ramos (1989), o trabalho não é ocupação, todas as classes sociais detêm sua forma de ocupação, e todas as pessoas mantêm sua ocupação. Assim como o camponês, o proprietário, na medida em que conserva uma função, tem sua ocupação. O que caracteriza o operário ou trabalhador, no sentido mais restrito, é que ele trabalha para outra pessoa.

Segundo Bridges (1995), a palavra emprego, da língua inglesa, tem sua origem em 1400 d.C. Até o início do século XVIII, se referia a alguma tarefa ou determinada empreitada; nunca se referia a um papel ou a uma posição numa organização. A partir do século XIX, passou a ser entendida como o trabalho realizado nas fábricas ou nas burocracias das nações em fase de industrialização. O emprego é um fenômeno da modernidade. O emprego é uma consequência específica do capitalismo. Ele é o elo formal entre o trabalhador e o modo de produção capitalista. Por outro lado, o desemprego é caracterizado como sendo a não possibilidade do trabalho assalariado nas organizações (empresas) de um modo geral. Podemos dizer que desemprego significa a condição da pessoa sem algum meio aceitável de ganhar a vida e os desempregados são pessoas capazes de trabalhar para satisfazer suas necessidades, mas sem renda.

A conotação moderna do termo emprego reflete a relação entre o indivíduo e a organização onde uma tarefa produtiva é realizada, em que o trabalhador (individuo) recebe pagamento pelas atividades executadas (pelo trabalho) em uma economia de mercado. A partir do século $\mathrm{XX}$, os empregos tornaram mais comuns e importantes pelo fato de se tornarem o caminho quase único e disponível para a segurança e satisfação das necessidades de sobrevivência do trabalhador, na vida em geral. Entretanto, no mundo atual quando se trata de emprego, o que vemos com maior frequência é o desemprego, desencadeado pela revolução tecnológica e, sobretudo, pela legislação aprovada no Congresso Nacional, tais como a Lei da Terceirização e da Reforma Trabalhista. Bridges (1995, p.36-37), reforça este raciocínio, afirmando que, “(...) agora, porém, estão desaparecendo da paisagem econômica. 
Igual a muitas espécies pegas no fluxo e refluxo da evolução, os empregos emergiram sob um conjunto de condições e agora começaram a desvanecer-se sob outro".

Em resumo, temos os termos emprego, desemprego, desempregado e empregador que são expressões diferente das noções de trabalho e de trabalhador. Emprego é um conceito que surgiu dentro contexto da Revolução Industrial. Emprego significa uma relação entre homens que vendem a sua força de trabalho por um valor para os proprietários dos meios de produção (empresários). É uma espécie de contrato em que os donos dos meios de produção paga pelo trabalho de outrem - o trabalhador. Desemprego indica a não oferta de postos de trabalhos. Desempregado refere ao trabalhador que não tem um vínculo empregatício - sem renda. $\mathrm{E}$ empregador refere aos proprietários dos meios de produção - os empresários. O trabalho é a energia e a ação que o indivíduo executa em uma determinada tarefa remunerada. $\mathrm{O}$ trabalhador refere e representa a uma classe social dentro da sociedade capitalista que vende a sua força de trabalho aos capitalistas ou empresária. Ou seja, a única mercadoria que o trabalhador tem para vender dentro da sociedade capitalista, é a sua força de trabalho. O seu valor está condicionado pela lógica do mercado.

Marx (1961) coloca que:

(...) a força de trabalho, então, era a capacidade de trabalhar ou trabalho potencial. Quando a força de trabalho era vendida como mercadoria, seu valor de uso era, simplesmente, a execução do trabalho - o incorporado à mercadoria, dando-lhe, assim, valor. Portanto a única fonte possível de maisvalia era a diferença entre o valor do poder de trabalho como mercadoria (ou trabalho potencial) e o valor da mercadoria produzida, que incorporava o trabalho concretizado (ou valor de uso consumido da força de trabalho). A força de trabalho era uma mercadoria absolutamente única: seu consumo ou uso criava novo valor, que bastava não só para substituir seu valor original, como também para gerar mais-valia. (...) A existência da força de trabalho como mercadoria dependia de duas condições essenciais. Primeiramente, a força de trabalho pode aparecer no mercado como mercadoria somente se na medida em que seu dono - o indivíduo que tem esta força de trabalho - a oferecer à venda como mercadoria. Para que ele possa fazer isso (...) terá que ser, sem qualquer impedimento, o dono de sua capacidade de trabalho, isto é, de sua pessoa (...) o dono da força de trabalho tem que vendê-la apenas durante certo tempo, pois, se tivesse que vendê-la totalmente e para sempre, estaria vendendo a si próprio, transformando-se de homem livre em escravo, de dono de uma mercadoria em uma mercadoria (...) a segunda condição essencial é que o trabalhador, em vez de ficar na posição de vender mercadorias nas quais seu trabalho está incorporado, fica obrigado a oferecer à venda como mercadoria a própria força de trabalho, que só ele tem. (MARX, 1961, 168-169).

Nas palavras de Marx (1961), o trabalho é que gera a mais-valia para os donos dos meios de produção para quem os trabalhadores vendem a sua força de trabalho. A força de 
trabalho é uma mercadoria como qualquer outra, que pode ser vendida. O trabalhador vende a sua força de trabalho, portanto, é uma mercadoria. O trabalhador terá um tempo para vender a sua força de trabalho, porque se vender para sempre, não será um homem livre, tornara um individuo escravo. Essa condição social do trabalhador torna-o subordinado a lógica do capital e dos interesses capitalistas. Ou seja, se a força de trabalho é uma mercadoria, logo o capitalista compra esta mercadoria pelo menor preço dentro da lógica da economia de mercado. Se há muitos trabalhadores desempregados, logo, a força de trabalho pode ficar mais barata.

No que diz respeito ao debate teórico sobre o conceito de desenvolvimento humano principalmente nas ciências sociais, via de regra, deve primar-se em uma visão interdisciplinar. Silva; Panhoca, (2007), afirmam que o conceito de desenvolvimento humano parte do pressuposto de que para aferir o avanço de uma população, não se deve considerar apenas, a dimensão econômica, mas também, outras características sociais, culturais e políticas e outras dimensões tais como sexuais, psicossociais e cognitivas. Moura e Pereira (2017) afirmam que para o Programa das Nações Unidas para o Desenvolvimento Humano (PNUD), o desenvolvimento emerge como um processo de ampliação das liberdades das pessoas, com relação às suas capacidades e as oportunidades a seu dispor, para que elas possam escolher a vida que desejam ter. Essa perspectiva engloba fatores econômicos, ambientais, políticos e sociais, considerados relevantes na efetivação de muitas possibilidades para as pessoas, acompanhados da existência de um contexto que promova o exercício pleno de seu potencial.

O PNUD sinaliza que apesar da renda e dos recursos financeiros serem relevantes, o crescimento econômico deixa de ser primordial e passa à condição de mediador, sendo superado pelo fator humano. Esta concepção reforça a ideia da renda e dos recursos concebidos como meios do desenvolvimento, não mais se configurando seu próprio fim. Todavia, o PNUD desenvolveu o Índice de Desenvolvimento Humano (IDH) como alternativa ao indicador econômico baseado no Produto Interno Bruto (PIB), que durante muitos anos foi a única medida do desenvolvimento. (MOURA; PEREIRA, 2017)

É importante lembrar que o Índice de Desenvolvimento Humano Municipal, no caso brasileiro, é elaborado a partir dos dados estatísticos fornecidos pelo IBGE. Esse processo de contabilização e organização dos dados estatísticos do PNUD é executado a partir da parceria com o IBGE. O IDH representa um conjunto de indicadores sociais para avaliação de desenvolvimento humano. Temos o Índice de Desigualdade de Gênero (IDG) que mensura as desigualdades com base no gênero em três dimensões - saúde reprodutiva, autonomia e 
atividade econômica. A saúde reprodutiva é medida pelas taxas de mortalidade materna e de fertilidade entre as adolescentes; a autonomia é medida pela proporção de assentos parlamentares ocupados por cada gênero e a obtenção de educação secundária ou superior por cada gênero; e a atividade econômica é medida pela taxa de participação no mercado de trabalho para cada gênero.

Em 1997 surge o Índice de Pobreza Humana (IPH) no Relatório de Desenvolvimento Humano - RDH para auxiliar no processo de avaliação das conjunturas de pobreza e de privação multidimensionais com o acesso à saúde, nutrição ou habitação, enquanto situações de entrave ao desenvolvimento humano, principalmente ao nível dos Estados do hemisfério sul. O Índice de Pobreza Multidimensional (IPM) identifica privações múltiplas em educação, saúde e padrão de vida nos mesmos domicílios. Todos os indicadores necessários para elaborar o IPM para um domicílio são obtidos pela mesma pesquisa domiciliar. O IPH procura computar tanto o número de pessoas que são pobres multidimensionalmente como a intensidade da sua pobreza.

O IPM é definido segundo dez indicadores, concorrendo cada um deles de forma idêntica para a sua respectiva dimensão. São três as dimensões: saúde, educação e padrão de vida. Para a dimensão da saúde contam os indicadores referentes à taxa de mortalidade infantil e de nutrição. Para a dimensão da educação, os indicadores dos anos de escolaridade e do número de crianças matriculadas. Para a dimensão do padrão de vida, concorrem seis indicadores: o acesso a eletricidade; o acesso a água potável limpa; o acesso a saneamento apropriado; o acesso a combustível para cozinhar; o acesso a uma casa com pavimento de terra; e, não tendo carro, a propriedade, no máximo, de dois dos seguintes bens: bicicleta, moto, rádio, telefone e televisão, (PNUD, 2013).

Outro indicador social muito utilizado é o Índice de Gini, criado pelo matemático italiano Conrado Gini. É um instrumento para medir o grau de concentração de renda em determinado grupo. Ele aponta a diferença entre os rendimentos dos mais pobres e dos mais ricos. Numericamente, varia de zero a um (alguns apresentam de zero a cem). O valor zero representa a situação de igualdade, ou seja, todos têm a mesma renda. $\mathrm{O}$ valor um (ou cem) está no extremo oposto, isto é, uma só pessoa detém toda a riqueza. Na prática, o Índice de Gini costuma comparar os $20 \%$ mais pobres com os $20 \%$ mais ricos.

O IBGE utiliza outras variáveis para avaliar o grau de desenvolvimento de uma região ou do país tais como: renda per capta por município; renda familiar - per capita - média salário mínimo; evasão escolar - pessoas na faixa etária de 10 a 14 anos trabalhando (\%); esperança de vida ao nascer - ano; mortalidade infantil (por mil nascidos vivos); PIB 
municipal; domicílios com iluminação elétrica $-\mathrm{n}^{\mathrm{o}}$ de domicílios urbanos e rurais; população residente rural e urbana - habitante; população economicamente ativa rural e urbana, etc. Estes indicadores na verdade indicam ou apontam uma determinada tendência de evolução das condições sociais e trabalham com dados estatísticos abstratos e com coeficiente de media que pode não refletir o real.

Quanto a questão espacial do trabalho, Moreira (2000) afirma que cada era do trabalho implica em uma forma determinada de "arrumação do espaço" que o regula. A técnica é o elemento dinâmico dessa mudança. Toda vez que o período técnico muda, correlatamente muda a forma da regulação espacial, e assim o mundo do trabalho. Tem sido essa espécie de lei espacial a norma da organização do espaço da sociedade e do mundo do trabalho na história do capitalismo.

Para Thomaz Junior e Gonçalves (2002), a ordem do movimento de reprodução do capital constrói uma sociedade das mais variadas expressões espaciais e territoriais a partir da dinâmica do trabalho. Para estes geógrafos, a organização/reorganização da sociedade para a produção implica, além de um redimensionamento do trabalho, em uma reorganização espacial e territorial da sociedade. Essa reorganização espacial e territorial do mercado de trabalho traduz na divisão territorial do trabalho nas mais variadas escalas espaciais desde a clássica Divisão internacional do Trabalho até a escala local.

A divisão territorial do trabalho ensejada pelo capital está articulada tanto à necessidade expansiva do capital, quanto à geografia própria do capital. Isso significa que ao expandir, reproduz as desigualdades espaciais, com valorização em alguns lugares e desvalorização em outros. Essa lógica do capital, ou seja, a mobilidade geográfica do capital é que desenha as varias regiões consideradas desenvolvidas, subdesenvolvidas, ricas e pobres, portanto, redesenhando a divisão territorial do trabalho. O desenvolvimento desigual do capitalismo promove a transformação e cria mercados de trabalho regionalmente diferenciados.

Segundo Carvalhal (2008), o desemprego e a precarização do emprego não são variáveis tecnicamente neutras, que não possam ser analisadas sob o crivo da luta de classes. Pois, a adoção seletiva dos paradigmas técnicos e organizacionais da reestruturação produtiva atinge desigualmente os setores econômicos e os lugares da acumulação capitalista, construindo a territorialidade do capital. Tal territorialidade tem no deslocamento escalar e temporal, trunfos que utiliza para exercer seu domínio sobre a totalidade social, ora unificando campo e cidade sob o paradigma do assalariamento, ora promovendo 
diferenciações nas relações de trabalho, como a subordinação da mão de obra familiar através dos contratos de integração.

Com a chegada do século XX e do XXI, o avanço tecnológico leva à substituição dos trabalhadores por máquinas nas atividades que demandam esforços físicos e não físicos, ocasionando o "desemprego tecnológico". É uma situação indesejável para o trabalhador, pois, provoca o desemprego e, os que são readmitidos, voltam a trabalhar com um salário, em média, 30\% menor do que o salário anterior. Perante a esta situação, o desafio é grande para os trabalhadores. A questão é a seguinte: como se poderá garantir a sobrevivência das pessoas em tais condições? Uma das alternativas seria possível através da luta e da mobilização politicamente organizada da classe dos trabalhadores.

Segundo Woleck (2002, p. 10), o capitalismo contemporâneo vem, nas últimas décadas, engendrando profundas mudanças no mercado de trabalho. Essas mudanças se expressam, principalmente, pela globalização das finanças, pela crescente precarização das relações de trabalho, pelas taxas elevadas de desemprego, pelo deslocamento geográfico de organismos produtivos e absorvedores de mão-de-obra e pela eliminação de postos de trabalho na indústria e nos serviços. Essas mudanças colocam o modo de produção capitalista como uma sociedade capitalista muito dinâmica, mas também, muito perversa.

O modo de produção capitalista para continuar sobrevivendo é necessário constantemente, reestruturar as suas bases de produção no espaço geográfico. Essa reestruturação é corriqueira nos momentos de crise do modo de produção. As crises do capitalismo são constantes, elas apenas mudam de lugar para lugar. Para contornar as crises e continuar a reprodução do processo de acumulação capitalista, há necessidade de se reestruturar as bases de produção. A reestruturação pode surgir de duas formas: pela mobilidade geográfica do capital, ou seja, nesta mobilidade o capital precisa ocupar novos espaços e novos mercados. E a reestruturação tecnológica que é mais corriqueira, impacta diretamente no mercado de trabalho.

Em outras palavras, o mercado de trabalho se torna uma variável, que pode ter a sua dinâmica de acordo com as crises e reestruturação dos meios de produção capitalista. É a partir deste referencial teórico que é feita a análise sobre a dinâmica e o desempenho do emprego em Porto Nacional-TO.

\section{Análises e interpretação dos resultados e discussões}


Durante a pesquisa foi possível constatar algumas tendências e desempenho dos indicadores sociais em Porto Nacional-TO. Porto Nacional ocupa a $764^{a}$ posição entre os 5.565 municípios brasileiros segundo o IDHM. Nesse ranking, o maior IDHM é 0,862 (São Caetano do Sul) e o menor é 0,41 8 (Melgaço-PA) conforme dados do PNUD (2013). Ou seja, é uma posição razoável do município, no contexto nacional no que diz respeito aos indicadores de desenvolvimento humano perante aos demais municípios brasileiros. O IDH do município teve uma sensível melhora nas últimas três décadas, evoluindo de 0,424 e 1991 para 0,740 em 2010 (IBGE, 2010).

Segundo o Censo Demográfico de 2010 do IBGE, o município tinha 49.146 habitantes, 42.435 urbanos e 6.711 rurais, o que caracteriza um município com alta taxa de urbanização. Segundo dados do Censo Demográfico do IBGE, Porto Nacional tem 13.774 domicílios particulares permanentes, destes 3.495 domicílios com classes de rendimento nominal mensal domiciliar de 1 a 2 salários mínimos. Se estabelecermos uma estimativa que cada domicilio tenha 5 pessoas, então teremos um total de 8.430 pessoas, o que representa mais $1 / 5$ da população urbana para o ano de 2010, com rendimento entre meio a um salário mínimo. Isto é, é um cenário que indica um desempenho ruim para o desenvolvimento humano para o município.

Gráfico 1- Grau de instrução dos trabalhadores em Porto Nacional - TO, 2010.

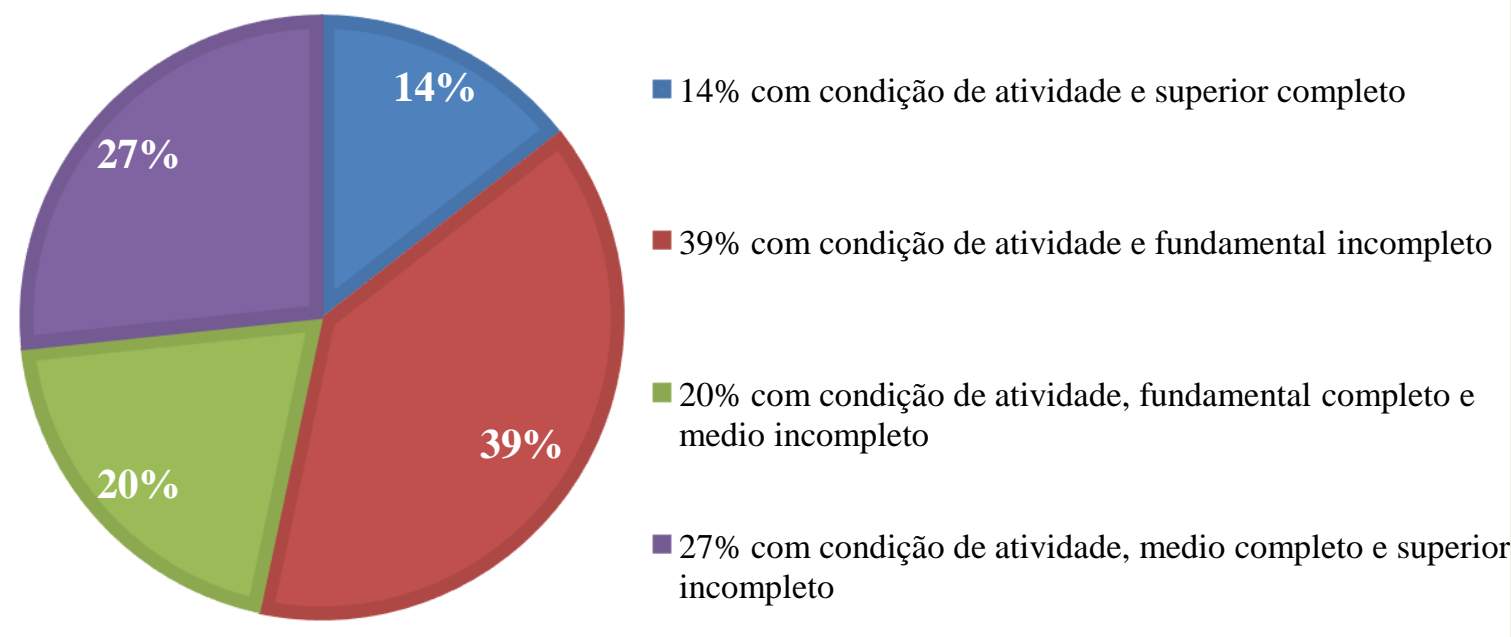

Fonte: IBGE, Censo Demográfico 2010 Org. MOURA. 2017

A análise dos dados estatísticos levantados nos bancos de dados online do IBGE e PNUD sobre o emprego e trabalho que utilizamos como amostra os dados dos anos 2010, nos possibilitou ter um conhecimento empírico da realidade social e econômica do objeto em pauta. De acordo com as pesquisas realizadas no IBGE, Censo de 2010, as pessoas com 10 Geopauta, Vitória da Conquista, ISSN: 2594-5033, V. 4, n. 2, 2020, (p. 5-29) http://periodicos2.uesb.br/index.php/geo, 
anos ou mais de idade que estavam em condição de atividade, ou seja, estavam trabalhando, possuíam desde o nível fundamental incompleto até o nível superior completo. Entretanto, as pessoas com grau de instrução educacional no nível fundamental incompleto eram a maioria no mercado de trabalho, representando assim um total de $35 \%$ dos trabalhadores, e apenas, 13\% dos trabalhadores possuíam nível de instrução educacional superior completo, como está exposto no gráfico $\mathrm{n}^{\circ} 1$.

No gráfico 2, podemos perceber que o número de trabalhadores com carteira assinada tem um índice indesejável, segundo os dados do IBGE - Censo Demográfico de 2010, representando apenas $48 \%$ do total. E no que diz respeito aos trabalhadores sem carteira assinada, os números correspondem a $52 \%$ do total. Essa constatação constitui um dado desanimador, ou seja, ter menos trabalhadores com carteira assinada do que sem carteira assinada, este fato representa tendências negativas para o mercado de trabalho e para os índices de desenvolvimento humano no município.

Gráfico 2 - Proporção de trabalhadores com e sem carteira de trabalho assinada - 2010

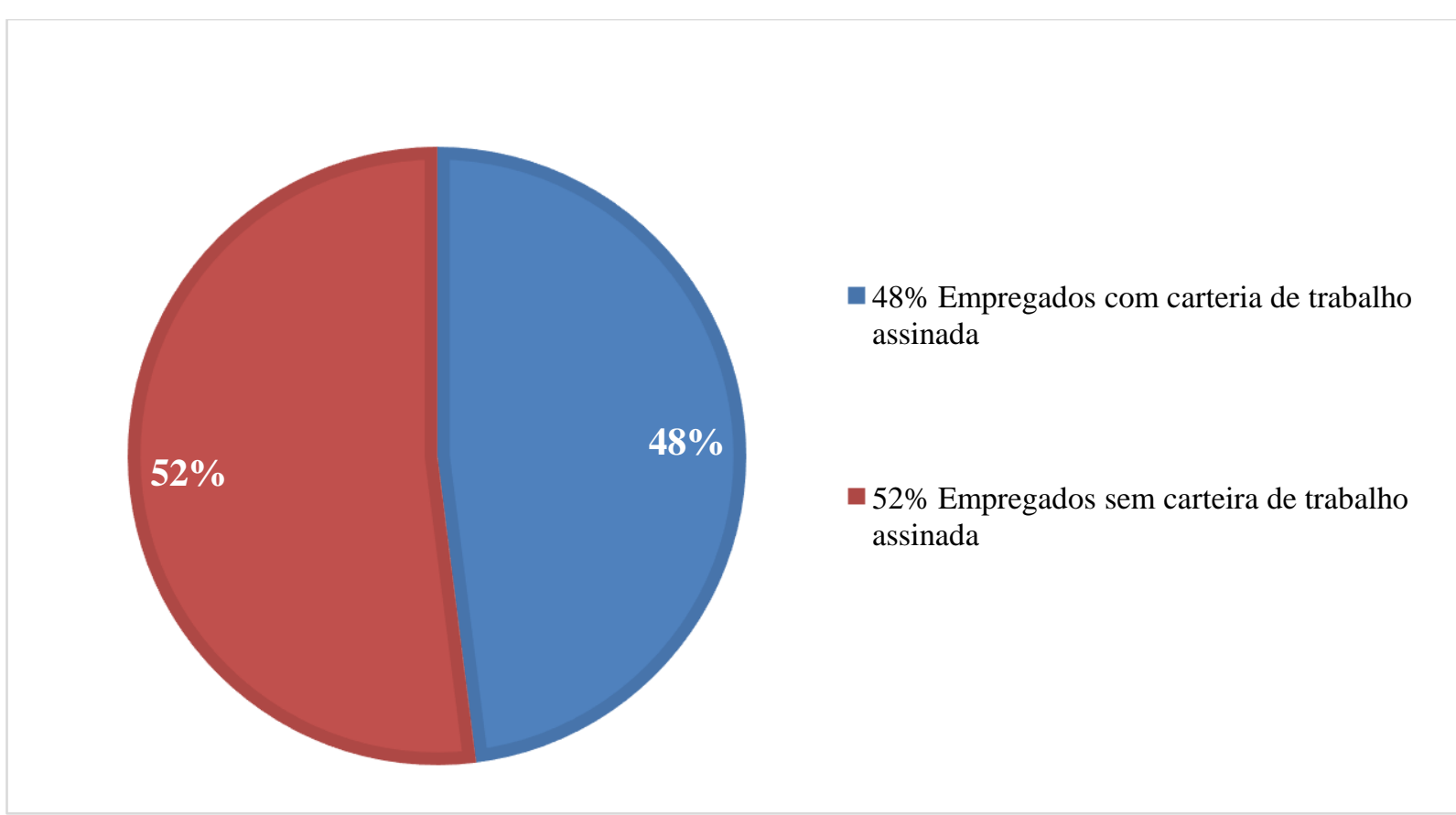

Fonte: IBGE, Censo Demográfico 2010. Org. MOURA, 2017.

Analisando as tendências de oferta de emprego formal em Porto Nacional-TO, conforme entrevista realizada nos sindicatos do município em estudo, foi possível observar a dinâmica e desempenho do emprego formal. Segundo o Sindicato Regional dos Trabalhadores Rurais, os serviços prestados às empresas, foram uma das áreas de emprego formal que mais ofertaram postos de trabalho no período de 1995 e 2014. O Sistema Nacional de Emprego 
(SINE) considerou a área de construção civil e dos serviços domésticos. O Sindicato dos Empregados do Comércio também considerou as áreas de construção e comércio como sendo as áreas que produziram maior número de ofertas de empregos na cidade de Porto Nacional no período de 1995 a 2014, como descrito no gráfico no 3 .

Gráfico 3- Postos de trabalho ofertado em Porto Nacional - TO entre 1995 e 2014

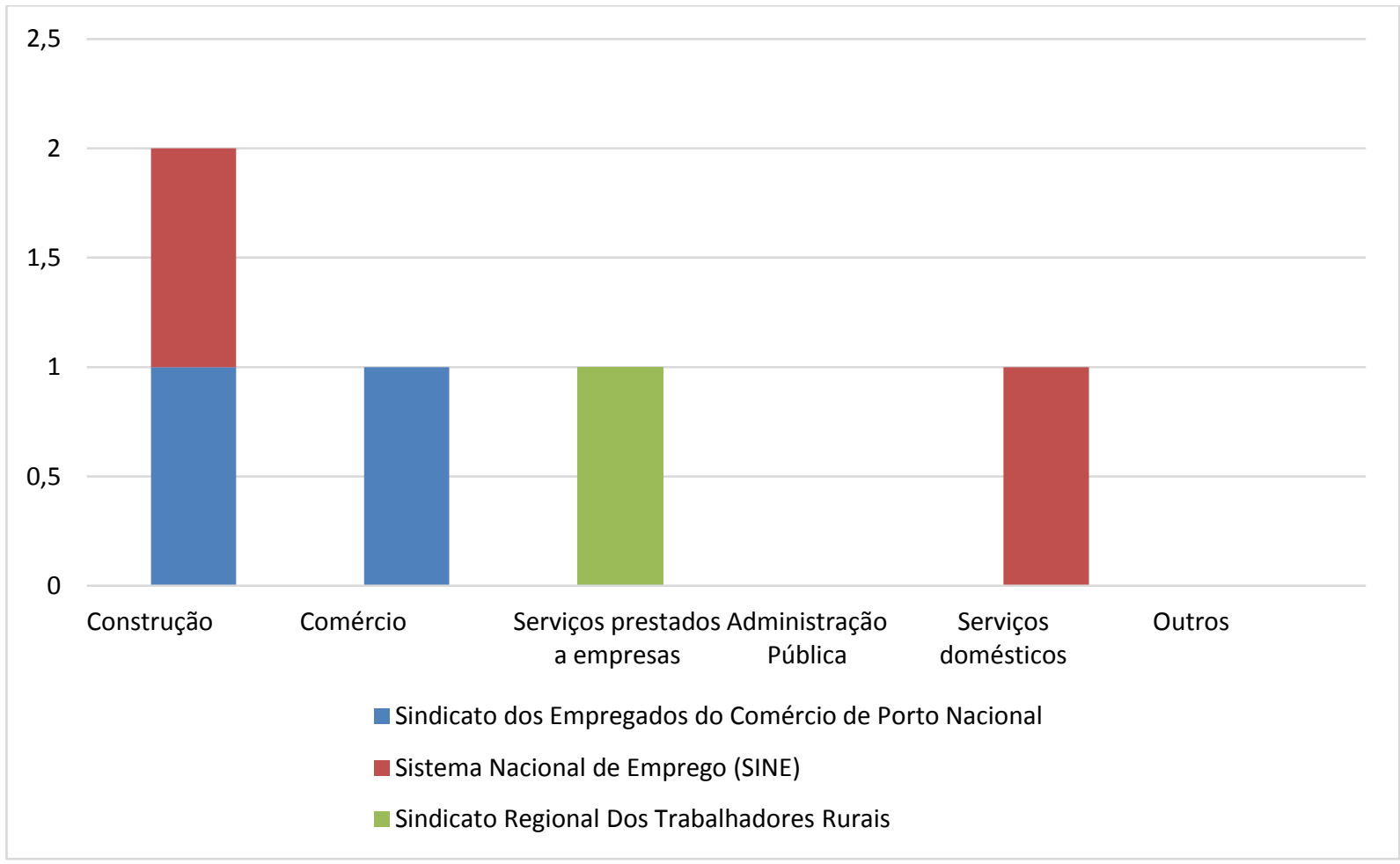

Fonte: Sindicatos de Porto Nacional - TO, 2016. Org. MOURA, 2017

Em relação aos setores de oferta de emprego formal à população no período de 1995 a 2014, segundo o Sindicato Regional dos Trabalhadores Rurais e o Sistema Nacional de Emprego (SINE), foi o setor privado que mais ofertou emprego formal. O Sindicato dos Empregados do Comércio considerou também o setor privado como o que mais ofertou emprego à população, e também destacou o setor dos funcionários públicos e por conta própria como setores que ofereceram trabalhos no período analisado, conforme descreve o gráfico 04. O setor privado é o que mais ofertou emprego formal, mas também o emprego informal. Todos os entrevistados foram unânimes em afirmar que o setor privado foi o que mais ofertou emprego formal no período analisado. 
Gráfico 4- Setores de emprego com maior número de oferta em Porto Nacional - TO entre 1995 e 2014

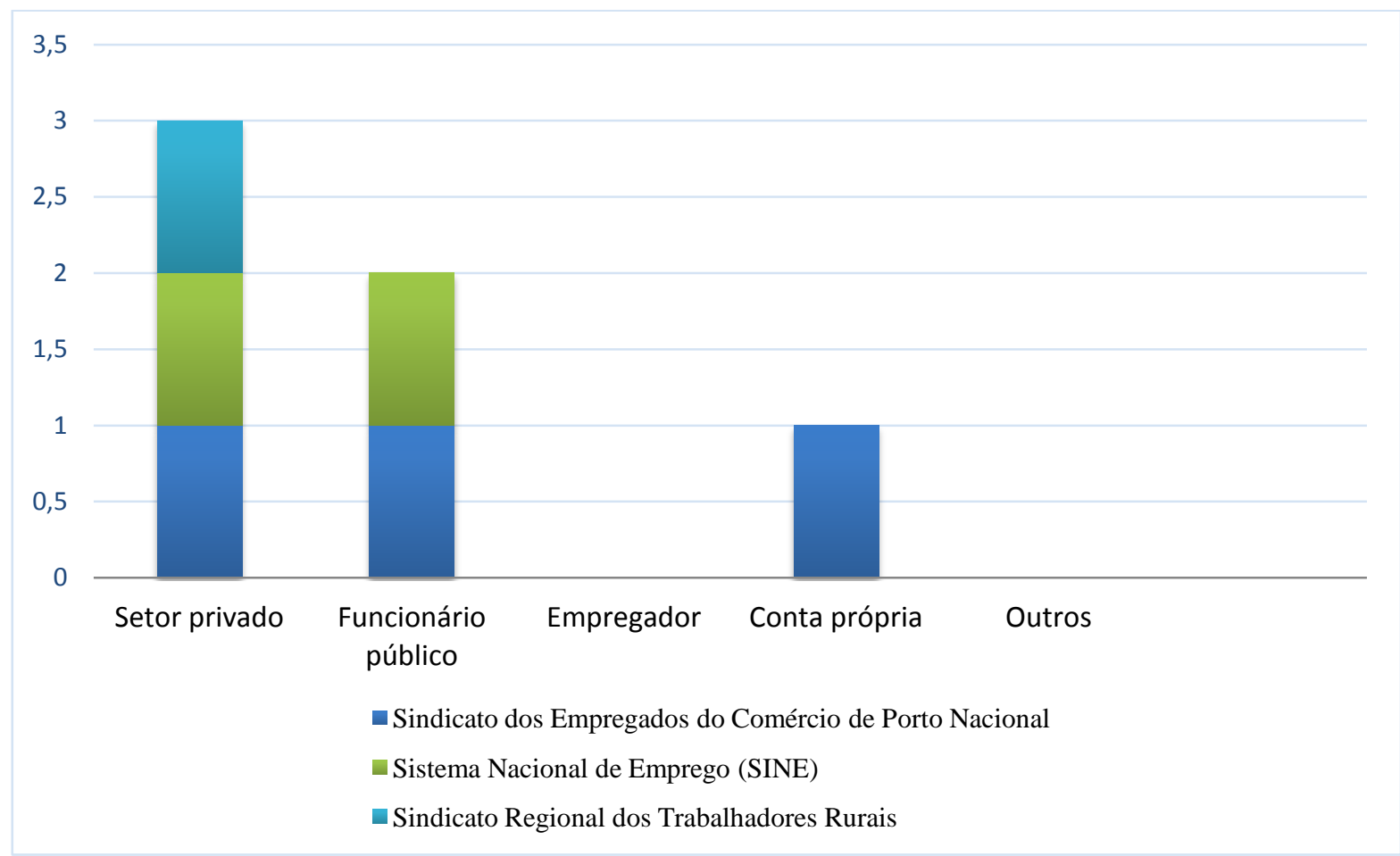

Fonte: Sindicatos de Porto Nacional - TO, 2016. Org. MOURA, 2017.

O Sindicato Regional dos Trabalhadores Rurais em entrevista destacou que as áreas da construção, do comércio e outros tais como o comércio da soja e milho se mantiveram com crescimento no quesito de trabalhadores com carteira assinada. O Sistema Nacional de Emprego (SINE) e o Sindicato dos Empregados do Comércio foram unânimes em afirmar que o comércio como um dos setores com maior número de trabalhadores com carteira assinada, conforme ilustra o quadro 05. Todos os entrevistados foram unânimes em afirmar que o setor do comercio foi o que mais ofertou empregos formais no período analisado. Em Porto Nacional, o setor de comercio é uma das atividades econômicas que mais oferta mão de obra, os setores industriais e agroindustriais ainda são incipientes. A atividade econômica baseada no agronegócio, nos últimos anos, vem se ampliando sua expansão no município, sobretudo, o cultivo da soja.

Os setores de emprego que se mantiveram em crescimento no período de 1995 a 2014, na cidade de Porto Nacional, segundo o Sindicato Regional dos Trabalhadores Rurais foi apenas o setor de construção. O Sistema Nacional de Emprego (SINE) considerou o setor de serviços de construção e comércio e outros como o setor da soja e do milho, que se mantiveram em alta. O Sindicato dos Empregados do Comércio destacou o setor de construção, do comércio e da administração pública como setores que se mantiveram em 
crescimento no mesmo período, conforme mostra o gráfico $n^{\circ} 6$. Todos os entrevistados foram unânimes em afirmar que o setor de construção foi o que mais houve crescimento no período analisado.

Gráfico 5- Áreas de serviço com trabalhadores de carteira assinada em Porto Nacional - TO entre 1995 e 2014

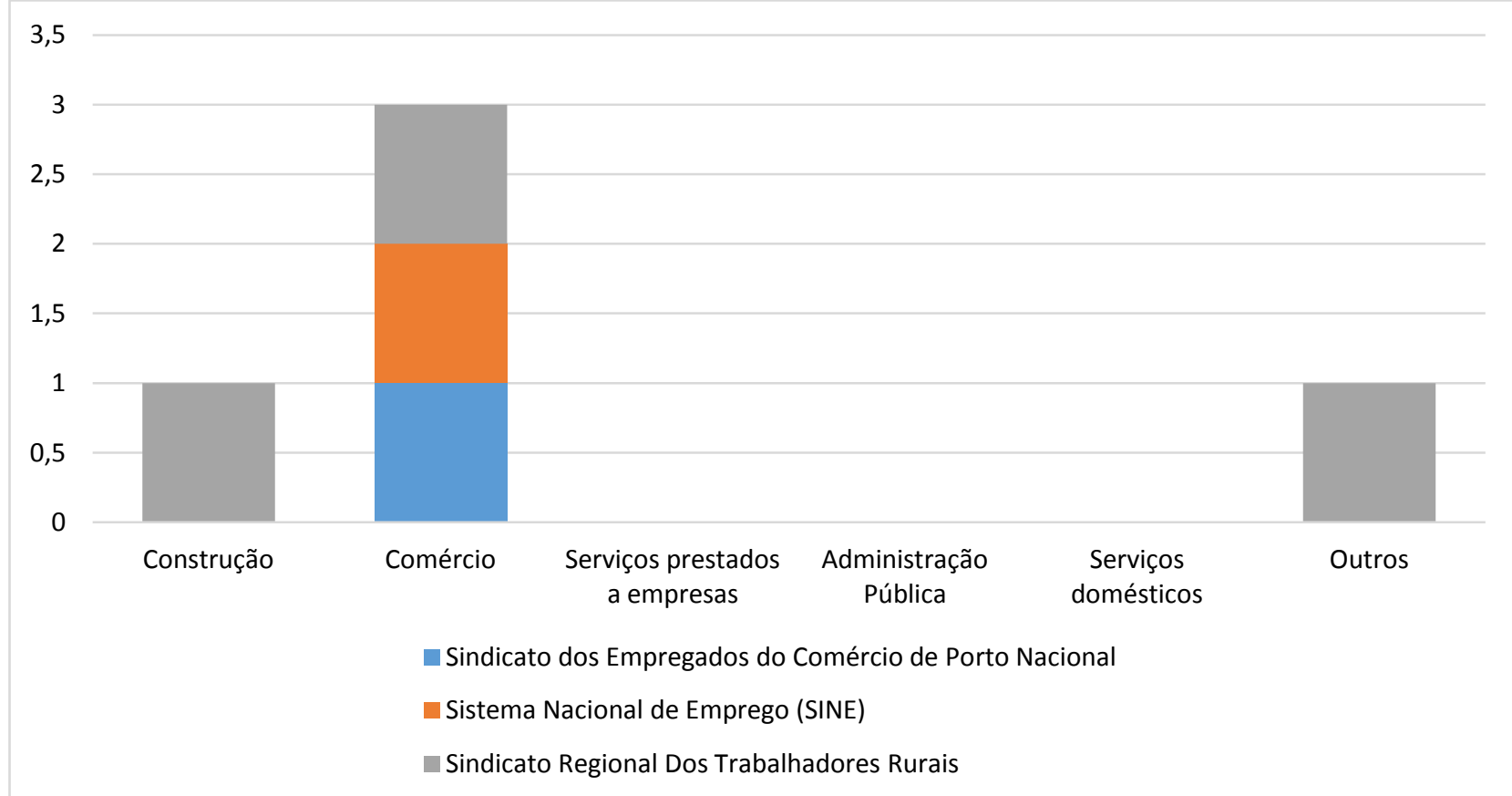

Fonte: Sindicatos de Porto Nacional - TO, 2016. Org. MOURA, 2017

Ainda, de acordo com a oferta de empregos por setores, as pessoas ocupadas na faixa etária de 18 anos ou mais do município, $12,70 \%$ trabalhavam no setor agropecuário, $0,10 \%$ na indústria extrativa, $5,46 \%$ na indústria de transformação, $9,76 \%$ no setor de construção, $0,83 \%$ nos setores de utilidade pública, $13,49 \%$ no comércio e $46,70 \%$ no setor de serviços. O comércio e o setor de serviços juntos representam mais da metade da oferta de empregos para o ano de 2010, ou seja, são os setores da atividade econômica que se mais destacaram no período analisado (PNUD, 2013).

No quesito de qualificação profissional dos trabalhadores, os setores da atividade econômica que apresentaram crescimento no período analisado, segundo o Sindicato Regional dos Trabalhadores Rurais, foram os setores da construção civil e do comércio. O Sistema Nacional de Emprego (SINE) considerou tanto a construção e o comércio quanto a administração pública. E o Sindicato dos Empregados do Comércio de Porto Nacional considerou o setor de construção e de serviços prestados à empresa, que houve um crescimento em qualificação profissional, conforme o mostra gráfico número 07 a seguir. 
Todos os entrevistados foram unânimes em afirmar que o setor da construção civil foi o que mais apresentou qualificação profissional dos trabalhadores.

Gráfico 6- Setores de serviço que se mantiveram em crescimento em Porto Nacional-TO 1995 a 2014

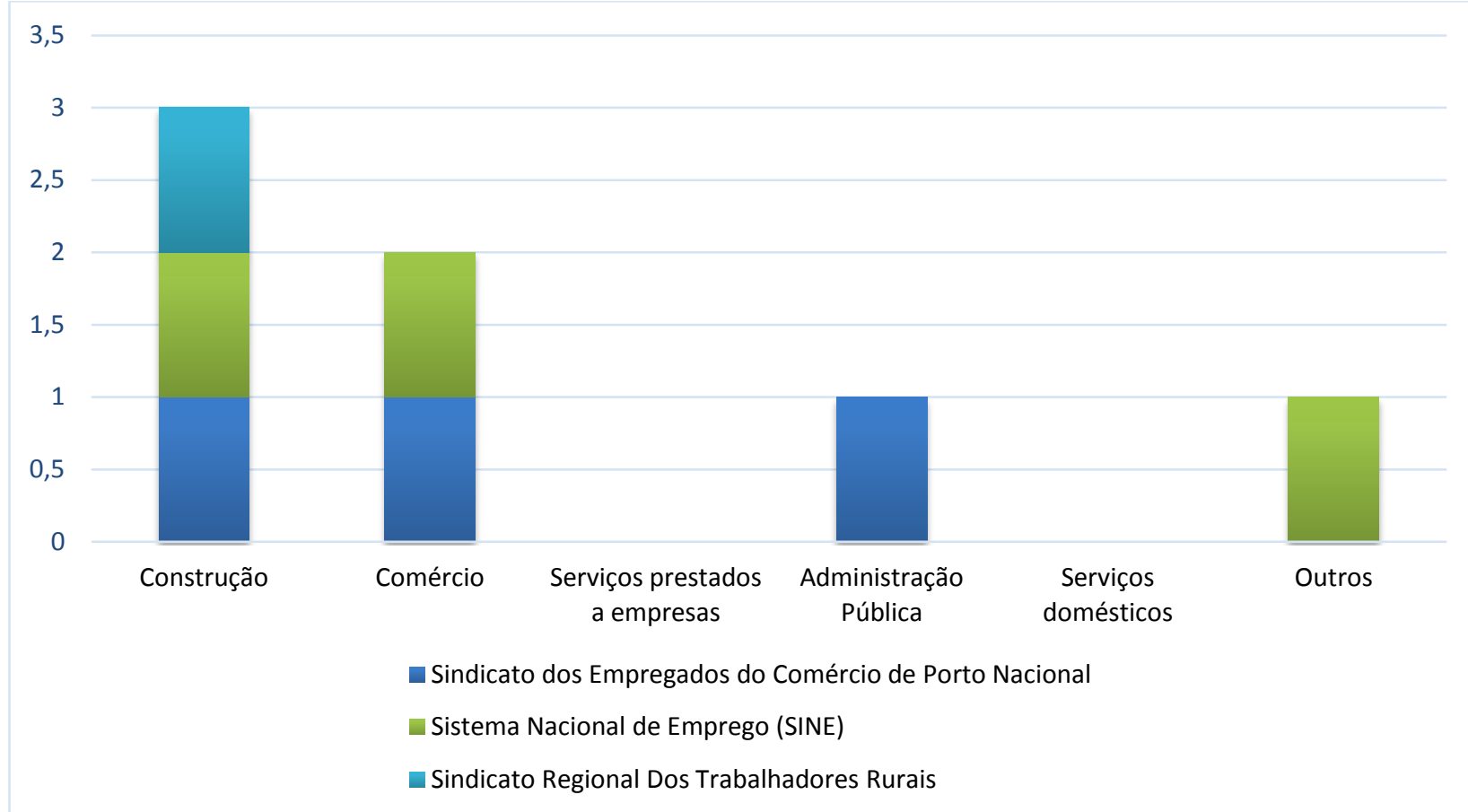

Fonte: Sindicatos de Porto Nacional - TO, 2016. Org. MOURA, 2017.

Quanto ao desenvolvimento humano, o que se observa é que se melhorar as condições de trabalho e aumentar a oferta de mais empregos formais, normalmente, haverá também melhorias nos índices de desenvolvimento humano. Mas o que está acontecendo nos últimos anos na sociedade capitalista é a precariedade das condições sociais do trabalho. Observar-se que, com o passar dos anos, houve transformações no mercado de trabalho no Brasil, como é o caso do trabalho informal, sobretudo, com a nova ordem ditada pelo capital mundializado, que tem afetado a vida dos trabalhadores, reforçando os índices de precarização do trabalho no país. Pois, há um grande contingente de trabalhadores que são obrigados a se sujeitarem a condições cada vez mais precárias, com baixos salários, péssimas condições de trabalho, perda de direitos trabalhistas, extensão da jornada de trabalho, entre outros, para sobreviver. Portanto, estes fatos contribuem para os baixos índices de desenvolvimento humano.

Em Porto Nacional, entre 2000 e 2010, o IDHM passou de 0,562 em 2000 para 0,740 em 2010 - uma taxa de crescimento de 31,67\%. O hiato de desenvolvimento humano, ou seja, a distância entre o IDHM do município e o limite máximo do índice, que é 1, foi reduzido em $59,36 \%$ entre 2000 e 2010. Nesse período, a dimensão cujo índice mais cresceu em termos 
absolutos foi educação (com crescimento de 0,295), seguida por longevidade e por renda. Entre 1991 e 2000, o IDHM passou de 0,424 em 1991 para 0,562 em 2000 - uma taxa de crescimento de $32,55 \%$. O hiato de desenvolvimento humano foi reduzido em $76,04 \%$ entre 1991 e 2000. Nesse período, a dimensão cujo índice mais cresceu em termos absolutos foi educação (com crescimento de 0,203), seguida por longevidade e por renda, (PNUD, 2013)

Gráfico 07- Setores da atividade econômica com crescimento em qualificação profissional em Porto Nacional - TO entre 1995 e 2014

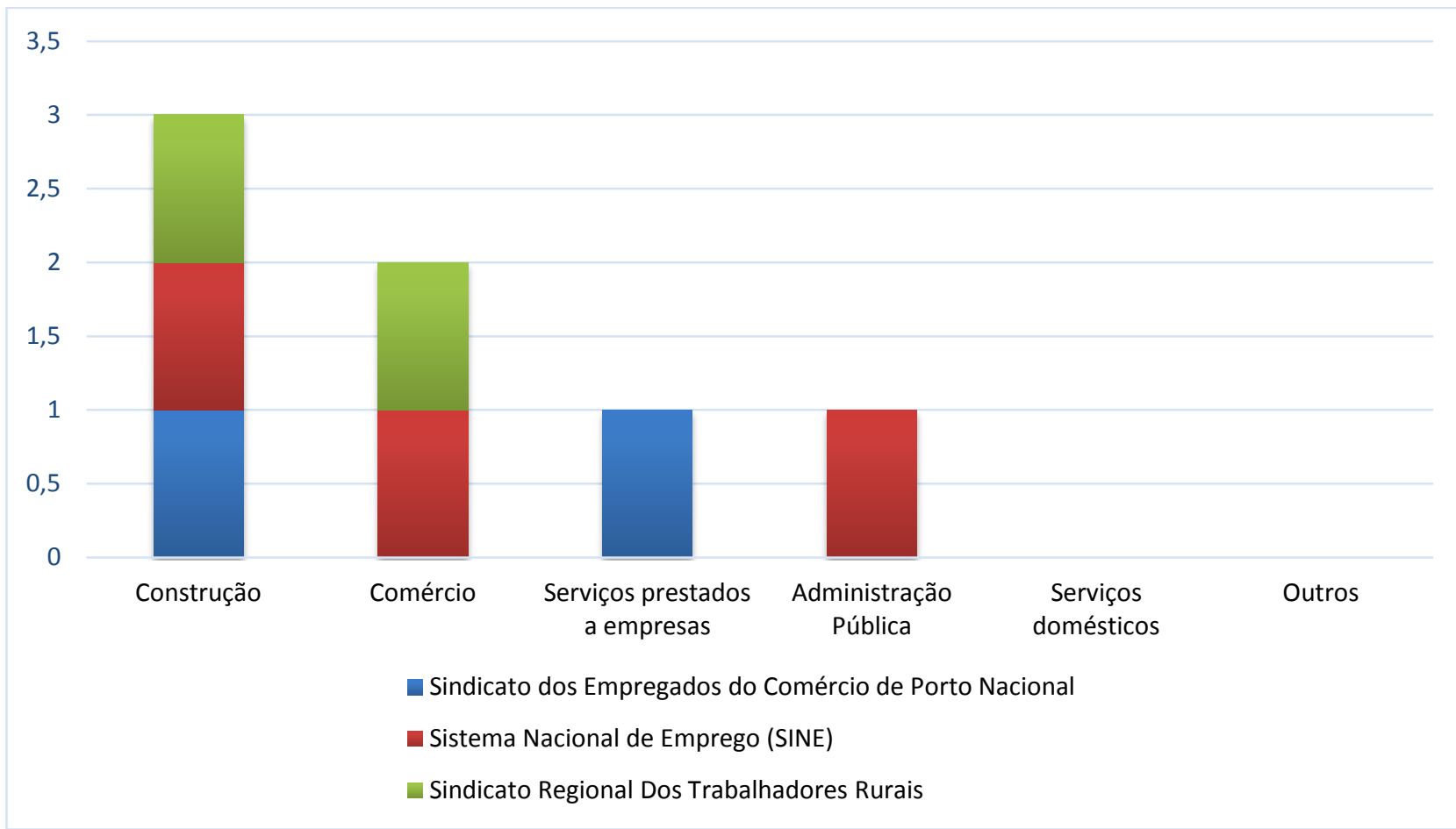

Fonte: Sindicatos de Porto Nacional - TO, 2016. Org. MOURA, Jaciara Araújo, 2017.

A renda per capita média de Porto Nacional cresceu 100,23\% nas últimas duas décadas, passando de $R \$ 310,20$, em 1991, para $R \$ 375,93$, em 2000, e para $R \$ 621,10$, em 2010 (PNUD, 2013). Isso equivale a uma taxa média anual de crescimento nesse período de $3,72 \%$. A taxa média anual de crescimento foi de $2,16 \%$, entre 1991 e 2000 , e $5,15 \%$, entre 2000 e 2010, conforme demonstra o Quadro n $^{\circ} 01$ a seguir. A proporção de pessoas pobres, ou seja, com renda domiciliar per capita inferior a $\mathrm{R} \$ 140,00$ (a preços de agosto de 2010), passou de 43,94\%, em 1991, para 37,54\%, em 2000, e para 13,79\%, em 2010, ou seja, houve uma evolução significativa, sobretudo entre 2000 e 2010. A evolução da desigualdade de renda nesses dois períodos pode ser descrita através do Índice de Gini, que passou de 0,58, em 1991, para 0,60, em 2000, e para 0,54, em 2010, conforme demonstra o Quadro 1. Neste 
quesito, podemos perceber que no município de Porto Nacional houve uma dinâmica desejável dos indicadores sociais listados no Quadro 1.

Entre 2000 e 2010, a taxa de atividade da população de 18 anos ou mais (ou seja, o percentual dessa população que era economicamente ativa) passou de 66,62\% em 2000 para 70,65\% em 2010. Ao mesmo tempo, sua taxa de desocupação (ou seja, o percentual da população economicamente ativa que estava desocupada) passou de 14,40\% em 2000 para 6,17\% em 2010. Quanto ao grau de formalização dos ocupados de 18 anos ou mais, houve uma pequena evolução e, com relação ao nível educacional dos ocupados também houve uma evolução, principalmente do percentual dos ocupados com ensino médio completo com 18 anos ou mais, o que é desejável.

Quadro 1- Renda, Pobreza e Desigualdade - Município - Porto Nacional - TO

\begin{tabular}{|l|l|l|l|}
\hline \multirow{2}{*}{ Indicadores sociais } & \multicolumn{3}{|c|}{ Anos } \\
\cline { 2 - 4 } & 1991 & 2000 & 2010 \\
\hline Renda per capita & 310,10 & 375,93 & 621,10 \\
\hline$\%$ de extremamente pobres & 19,94 & 15,44 & 4,03 \\
\hline \% de pobres & 43,94 & 37,54 & 13,79 \\
\hline Índice de Gini & 0,58 & 0,60 & 0,54 \\
\hline
\end{tabular}

Fonte: Atlas do Desenvolvimento Humano, PNUD, Ipea e FJP 2010. Org. Santos, 2018.

Com relação ao rendimento médio, no item percentual dos ocupados com rendimento médio de até um salário mínimo houve uma queda, no quesito de percentual dos ocupados com rendimento médio de até 2 salários mínimos também houve uma queda. E no quesito de 5 salários mínimos também houve uma queda menor, conforme mostra o Quadro $n^{\circ} 02$ a seguir. A queda do rendimento médio representa um fato negativo, lembrando que a maior queda incidiu sobre o rendimento médio de até 1 salário mínimo, o que é uma notícia péssima para o trabalhador de Porto Nacional.

Quadro 2- Ocupação da população de 18 anos ou mais no Município de Porto Nacional - TO

\begin{tabular}{|c|c|c|}
\hline Indicadores sociais & & Anos \\
\hline Taxa de atividade -18 anos ou mais & 2000 & 2010 \\
\hline Taxa de desocupação - 18 anos ou mais & 66,62 & 70,65 \\
\hline Grau de formalização dos ocupados -18 anos ou mais & 14,40 & 6,17 \\
\hline \multicolumn{3}{|l|}{ Nível educacional dos ocupados } \\
\hline$\%$ dos ocupados com fundamental completo- 18 anos ou mais & 45,92 & 65,59 \\
\hline$\%$ dos ocupados com médio completo -18 anos ou mais & 27,38 & 49,74 \\
\hline \multicolumn{3}{|l|}{ Rendimento médio } \\
\hline$\%$ dos ocupados com rendimento de até 1 s.m. -18 anos ou mais & 55,66 & 21,34 \\
\hline \% dos ocupados com rendimento de até 2 s.m. -18 anos ou mais & 80,38 & 73,33 \\
\hline$\%$ dos ocupados com rendimento de até 5 s.m. -18 anos ou mais & 94,59 & 91,54 \\
\hline
\end{tabular}

Fonte: Atlas do Desenvolvimento Humano, PNUD, Ipea e FJP 2010. Org. MOURA, 2018. 
Quando se trata da questão de gênero, os dados registrados sobre o rendimento mensal entre homens e mulheres apontam uma situação desanimadora para o ano de 2010. De acordo com os dados do quadro 3, podemos perceber que a medida que aumenta a renda nominal mensal baseada no salário mínimo, a tendência é que o contingente demográfico dos homens aumenta. Enquanto que no diz respeito ao rendimento mensal das mulheres, a tendência é mesma, mas não proporcionalmente a renda nominal mensal dos homens.

Por outro lado, há mais mulheres com rendimento médio ate 1/4 do salário mínimo (um total de 1.680) do que dos homens que é da ordem de 610, ao passo que no patamar de rendimento de mais de 1 a 2 salários mínimos, o total de homens pula para 4.221, enquanto para as mulheres, o total é da ordem de 2.679. Ou seja, para ter uma ideia mais compreensível a respeito, à medida que aumenta o rendimento médio, o número de homens aumenta de forma geométrica enquanto que no diz respeito ao número de mulheres, o aumento acontece de forma aritmética, conforme demonstra o (Quadro 3).

Quadro 3- Classes de rendimento nominal mensal de acordo com o gênero

\begin{tabular}{|c|c|c|}
\hline \multicolumn{3}{|c|}{$\begin{array}{l}\text { Resultados da Amostra - Rendimento: Pessoas de } 10 \text { anos ou mais de idade com Classes d } \\
\text { rendimento nominal mensal em } 2010 \text { em Porto Nacional-TO. }\end{array}$} \\
\hline De até $1 / 4$ de salário mínimo & Homens - 610 & Mulheres - 1.680 \\
\hline De mais de $1 / 4$ a $1 / 2$ salário mínimo & Homens - 432 & Mulheres - 1.024 \\
\hline De mais de 1 a 2 salários mínimos & Homens - 4.221 & Mulheres - 2.679 \\
\hline
\end{tabular}

Fonte: Censo Demográfico 2010: amostragem por municípios. Organização. (SANTOS; MOURA, 2016).

As antigas condições sociais continuam presente em Porto Nacional como as desigualdades sociais quanto ao mercado de trabalho e os índices que representam a pobreza regionais dentro do contexto nacional, embora, nos últimos anos, esta realidade vem caindo. As antigas desigualdades entre gênero continuam presentes no município entre os trabalhadores e trabalhadoras. Como ficou cristalino no quadro 03, em que a diferença de remuneração entre homens e mulheres ainda é grande, ou seja, as mulheres ainda continuam tendo uma remuneração menor do que os homens no mundo do trabalho. Os dados empíricos revelam uma realidade que infelizmente, ainda perpetuam em nossa sociedade capitalista. A geografia das regiões ricas e pobres continuam ainda aqui na Amazônia nas várias escalas espaciais, entre as unidades político-administrativas como é o caso de Porto Nacional.

\section{Considerações finais}

Acreditamos que a relevância da pesquisa, possa contribuir de forma significativa para o conhecimento sobre a dinâmica do emprego em Porto Nacional. Foi possível constatar que 
os diferentes setores da economia condicionaram as situações de emprego e das desigualdades entre as categorias de trabalhadores. Entre os setores de serviços, podemos perceber que entre estes, que a qualificação profissional dos trabalhadores acontece de forma diferenciada. Os dados analisados revelam que o mercado de trabalho em Porto Nacional, tem pela frente um grande desafio para ter um desempenho satisfatório para as melhorias das condições sociais dos trabalhadores.

Os resultados da análise dos dados estatísticos do PNUD e IBGE e das entrevistas, permitem-nos concluir que em Porto Nacional o setor do comercio e de construção civil, foram os que mais ofertaram mão de obra. Nos quesitos percentual extremamente pobre e percentual de pobres houve uma redução considerável, o que deixa o município em uma posição razoável perante o ranking dos indicadores sociais. Entretanto, o que podemos esperar para os trabalhadores, não é uma boa notícia para o futuro, sobretudo com a aprovação da nova legislação trabalhista.

Depois da aprovação da "reforma para os empresários" - a chamada Reforma Trabalhista de 2017, e oficialmente conhecida como a lei $\mathrm{n}^{\mathrm{o}} 13.467$, de 13 de julho de 2017, vai permitir uma maior precarização das condições sociais dos trabalhadores. Uma lei que assegura juridicamente o trabalho intermitente e, que o acordo entre patrão e empregado está acima da legislação trabalhista vigente, é uma notícia que deixa qualquer trabalhador assustado. E para deixar os trabalhadores mais indignados foi aprovado também, a Lei de Terceirização (Lei n ${ }^{\circ}$ 13.429, de 31 de março de 2017) que contribui para de forma definitiva para a precarização das condições sociais dos trabalhadores.

A estruturação do mercado de trabalho local e regional no Tocantins não foge a regra da divisão territorial do trabalho dentro do contexto brasileiro. Sabemos que a divisão social, técnica e principalmente a divisão territorial do trabalho é uma das formas de reprodução do modo de produção capitalista. A divisão territorial do trabalho cria espaços regionais diferenciados, como por exemplo, a divisão clássica - Divisão Internacional do Trabalho que cria um espaço global no formato centro-periferia. Essa lógica reproduz também nas varias escalas do processo - nacional, regional e local. O município de Porto Nacional é um recorte espacial que se materializa a divisão territorial e regional do trabalho. Os setores da atividade econômica como o do comercio, da construção civil e da agropecuária tem maior presença no município, fato que revela a baixa qualificação de mão de obra. O município ainda não é um polo industrial, tendo uma grande presença do setor primário e terciário na economia local e regional. 
Os indicadores sociais apontam e sinalizam o grau de desenvolvimento ou não que, em princípio, precisamos refletir de forma mais crítica sobre a análise de sua metodologia. $\mathrm{O}$ conceito de desenvolvimento e subdesenvolvimento é algo que pode ser criado a partir de critérios que representam a ideologia dominante dos países ricos. O geógrafo Yves Lacoste (1990), assegura que estes conceitos são construídos e organizados por estes países, como estratégia geopolítica para disciplinar e buscar a geopolítica do controle das políticas de desenvolvimento e de investimento na periferia do capitalismo.

Para o autor, o subdesenvolvimento é frequentemente apreciado sobre a base da avaliação dos produtos nacionais por habitante e por ano com valores do PNB per capta. O critério seria baseado em valores do PNB per capta nitidamente inferiores aos dos países desenvolvidos. Estes índices estatísticos que mensuram as condições de desenvolvimento ou não das nações, é uma das formas dos países ricos terem um mapa das condições sociais e econômicas global para articular a sua geopolítica de investimentos territorial.

Por outro lado, precisamos refletir um pouco mais sobre os indicadores sociais, que na verdade, representam uma média da renda nacional/anual e não representa uma distribuição social real da renda de um país. A ONU e os países ricos do Ocidente estabeleceram parâmetros e critérios para os países não desenvolvidos baseados nos critérios dos países desenvolvidos. A interpretação do subdesenvolvimento também passou por uma equivalência de uma situação econômica e social dita "atrasada", "arcaria", "tradicional", comparada à situação da Europa e pela ausência de um desenvolvimento industrial.

A ideia de qualificar o nível de subdesenvolvimento da população de uma metodologia multidimensional ou chamar um número de pessoas consideradas multidimensionalmente pobres é mascarar e, sobretudo, um procedimento sem uma reflexão mais aprofundada sobre a realidade real em nossa frente nos países mais pobres. É negar a sociedade constituída de classes em todos os cantos do planeta. Dentro do modo de produção capitalista, a nossa sociedade é composta por classes sociais diferentes. Não há agrupamento de indivíduos considerados ricos ou pobres. O que há na verdade, são as classes sociais nos seus mais variados níveis sociais de renda, presentes no centro ou na periferia do capitalismo. Os “remédios" das políticas públicas dos países mais ricos não vão acabar ou radicalizar a pobreza.

A pobreza e as contradições sociais no espaço são frutos e desdobramentos da lógica contraditória do modo de produção capitalista. O termo multidimensional indica vários itens que compõe a pobreza. E nem todos os itens que são necessidades da sociedade capitalista, 
são necessidades de outras sociedades e etnias. As necessidades dos europeus não são as mesmas para os africanos e latino-americanos.

\section{Referências}

ALBORNOZ, Suzana. O que é trabalho. 3.ed. São Paulo: Brasiliense, 1988.

PNUD - PROGRAMA DAS NAÇÕES UNIDAS PARA O DESENVOLVIMENTO. Brasília: Organização das Nações Unidas. Atlas do desenvolvimento humano no Brasil. Organização das Nações Unidas. Disponível em: http.www.pnud.org.br/atlas. Acesso em: 03 mar. 2016

BRIDGES, William. Mudanças nas relações de trabalho: como ser bem sucedido em um mundo sem empregos. São Paulo: Makron Books, 1995.

CARVALHAL, Marcelo Dornelis. O trabalho e a dinâmica territorial do capital. Revista Pegada - vol. 9 n.1, Junho/2008.

https://cidades.ibge.gov.br/brasil/to/porto-nacional/panorama, acessado em 20/10/2017.

IBGE -Censo Demográfico de 2000/2010, 2017.

MARX, Karl. O Capital. Moscou: Editora de Línguas Estrangeiras, 1961, 1:35, 3 v.

MARX, Karl. Contribuição à crítica da economia política. Trad. Maria Helena Barreiro Alves; revisão de Carlos Roberto F. Nogueira. 2.ed. São Paulo: Martins Fontes, 1983.

MOREIRA, Rui. Os períodos técnicos e os paradigmas do espaço e do trabalho. Rev. Ciência Geográfica, 2000, (Seção Bauru/AGB), Ano VI, Vol. II, no 16, maio/agosto, p. 0408.

MOURA, Eliana Perez Gonçalves de; PEREIRA, Gislaine Cristina. Desenvolvimento Humano - repensando conceitos no âmbito interdisciplinar. Revista Contrapontos Eletrônica, Vol. 17 - n. 4 - Itajaí, out-dez 2017.

RAMOS, Alberto Guerreiro. A nova ciência das organizações: uma reconceituação da riqueza das nações. 2.ed. Rio de Janeiro: FGV, 1989.

SANTOS Michelle Steiner dos. Um mundo sem empregos ou de desemprego: relações possíveis entre homem e trabalho para o século XXI. 1999. Dissertação (Mestrado.) Programa de Pós-Graduação em Engenharia de Produção e Sistemas, Universidade Federal de Santa Catarina, Florianópolis-SC. 1999.

SILVA, Olga Maria Panhoca da; PANHOCA, Luiz. A contribuição da vulnerabilidade na determinação do índice de desenvolvimento humano: estudando o estado de Santa Catarina. Ciência \& Saúde Coletiva, 12 (5):1209-1219, 2007

THOMAZ JUNIOR. Antonio; GONÇALVES, Marcelino Andrade. Informalidade e precarização do trabalho: uma contribuição à geografia do trabalho. Scripta Nova. Revista Electrónica De Geografía Y Ciencias Sociales. Barcelona. Vol. VI, nº 119 (31), $1^{\text {o }}$ de agosto de 2002. 
WOLECK, Aimoré. O trabalho, a ocupação e o emprego: uma perspectiva histórica. Associação Educacional Leonardo da Vinci - Curso de Especialização. 2002. Disponível em: Acesso em: 15 de jun. de 2016.

YVES. Lacoste. Geografia do Subdesenvolvimento. Tradução de T. Santos. $4^{\text {a }}$ Edição. DIFEL. São Paulo. 1975

\footnotetext{
Agradecimentos

O apoio financeiro do CNpq pela bolsa de PIBIC.
} 
Dinâmica e evolução do emprego e desenvolvimento humano em Porto Nacional-TO: perspectivas e realidades MOURA, J. A. de; SANTOS, R. de S.

Geopauta, Vitória da Conquista, ISSN: 2594-5033, V. 4, n. 2, 2020, (p. 5-29) http://periodicos2.uesb.br/index.php/geo, Este é um artigo de acesso aberto sob a licença Creative Commons da CC BY 